\title{
Dividend Announcement: Is It a Good News to the Bahrain Bourse?
}

\author{
Batool K. Asiri ${ }^{1}$ \\ ${ }^{1}$ College of Business Administration, University of Bahrain, Bahrain \\ Correspondence: Batool K. Asiri, College of Business Administration, University of Bahrain, Bahrain. E-mail: \\ batoolasiri@gmail.com
}

Received: September 15, 2014

Accepted: September 29, 2014

Online Published: November 25, 2014

doi:10.5539/ijef.v6n12p228

URL: http://dx.doi.org/10.5539/ijef.v6n12p228

\begin{abstract}
This paper presents a study of 157 dividend announcements made by 40 companies listed in the Bahrain Bourse and an examination of the relationship between dividend announcements and the stock market. The study lasted from 2004 to 2013, and the results indicate that investors have gained cumulative abnormal returns that average at 2.29 percent within the 30-day periods before and after the dividend announcement. Moreover, the findings have revealed that investors gained approximately 0.45 percent of the market value on all stocks that had increasing dividends; therefore, it can be reasonably concluded that, when announced to the public, dividend increases promote a positive message about a company's future growth and the promise of sustained cash flow. Alternatively, it could be seen as the Bahrain Bourse is inefficient in a semi-strong form. The study further highlights that abnormal returns gained by investors tend to vary across sectors. In general, the findings of this study fail to provide significant evidence in support of the dividends irrelevancy theory; on the contrary, they indicate that dividend payments act as positive signals that assure investors of steady cash flow and substantial future earnings.
\end{abstract}

Keywords: Bahrain bourse, cumulative abnormal returns, dividends announcement, event study

\section{Introduction}

The decisions management makes regarding the use of the corporation's cash flow inform the market price of the corporation's common stock, and are reflected in the profits of shareholders. Needless to say, these decisions are of great significance, and the allocation of dividends plays a large role in determining a company's efficiency and its overall ability to fulfill its fiscal objectives. In order to increase its fiscal value and potential for future growth, a company needs an effective policy to govern how it handles its dividends. The task of such policy development naturally falls to management. When the widely-held belief that any reduction in cash dividend payments is likely to result in a significant drop in a company's share prices is taken into consideration, it becomes clear that dividend policy has substantial implications for all stakeholders, including managers, investors and lenders, and those implications are often complicated. For instance, the number of dividends that a company is able to offer to shareholders reflects how much money will be accessible for investment in future projects since oftentimes, larger dividends result in limited access to funds for future investment. Dividend policy is relevant to investors because an investor's declared dividends have a dual function, constituting both the investor's regular income and serving as a principal factor in a firm's valuation. Lenders, too, have an equally prescient interest in the total dividends that a company offers. It is in the best interest of the lender to avoid large dividends, as an increase in dividends directly correlates to a reduction in available funds for redemption of claims. The shared impact of dividend payments by a number of different claimholders is a classic example of agency situation. When assessed from this perspective, dividend policy may be effective in reducing agency costs as they compel company managers to seek finance in capital markets and diminish the funds available for investment opportunities. Since, in these cases, these activities are monitored by external capital markets, managers may be motivated to act with additional care, and to keep the best interest of stakeholders in the foreground when making important fiscal decisions.

This paper seeks to answer the question of whether or not distribution of earnings creates actual value for shareholders in the Bahrain Bourse. The answer to this question lays in the study of dividend announcement, not distribution figures. Simultaneously, if the dividend announcement found to have an effect on the abnormal returns, the Bahrain Bourse is then considered to be inefficient in its semi-strong form. Thus, this study attempts to measure the behavior of the Bahrain Bourse in response to the dividend announcements of all the listed 
companies. It builds upon the methodology and findings of the previous study conducted by Asiri and Taleb (2012) and Hamid Uddin (2008). Certain finance moguls consider the effect of dividend announcements on the market to be a myth. However, in 1961 Miller and Modigliani made a groundbreaking claim, stating that although dividend policy does not seem to have a noteworthy effect on shareholder value under ideal economic circumstances, dividend payment announcements create a remarkable reaction in capital markets. This was evidenced by the positive reaction of stock prices to dividend increases and the negative of stock prices reaction to dividend decreases (Asquith \& Mullins, 1983; Michaely et al., 1995).

There is very little research in the field of finance literature that examines the effect of dividend "behavior" on emerging markets, and mainly Bahrain. However, the research that does, indeed exist, recognizes that dividend announcements are not an isolated activity but exist and are published in conjunction with information such as earnings data, which can distort results. Once it confronts the challenge of isolating the effects of dividend announcements, this research attempts to quantify the response of share prices to such dividend announcements in order to assess what effect such publications have on market behavior, to what degree firm payout policies are influenced by the profiles of their investor clientele and whether or not this response is favorable in relation to the nature of the data published. Yet the picture is still not complete. In order to achieve a better understanding of how dividends affect a firm's value, it is essential to analyze how investors behave in relation to dividend announcements. Such studies will not only illuminate the relationship between dividend announcements and investor behavior, but will also enhance any conclusions that have thus far been derived on this topic, and add depth to our understanding of the market.

\section{The Bahrain Bourse in Brief}

National Bank of Bahrain is the first Bahraini public shareholding company which was established in 1957. Since then, more local public shareholding companies began to operate, reaching their peak in the beginning of the 1980s. During this period, shares of public shareholding companies were being actively traded in a non-official market called "Al Jowhara Market". Such market soon collapsed along with the collapse of the Souk Al-Manakh stock market crash in Kuwait at the 1980s. However, due to the oil price boom in the region, Bahrain realized that there was a growing need for an organized stock market. The Amiri Decree No. 4 was issued in 1987, establishing the Bahrain Stock Exchange (BSE), which officially commenced operations on $17^{\text {th }}$ June 1989 with 29 companies listed on the Exchange. In 2010, the Bahrain Bourse was established as a shareholding company according to Law No. 60 to replace BSE. The Bahrain Bourse is considered as one of the most innovative stock markets in the region. Over the years, the Bahrain Bourse has grown to become one of the leading emerging stock markets in the region. In the year 2013, the listed companies increased to 47 companies, the shareholding equity amounted to BD 8,427,535 and the total assets to BD 9,397,052. Comparing the years 2012 to 2013, the Bahrain All share index increased by $17.2 \%$, the value of shares traded increased by $104.88 \%$, the volume of shares traded rose by $197.55 \%$ and the number of transactions increased by $39.62 \%$. The Commercial Banks sector captured $68.01 \%$ of the total trading value followed by Investment sector by $14.13 \%$, Services sector by $8.7 \%$, Industrial sector by $2.47 \%$, Insurance sector by $0.34 \%$ and Hotels \& Tourism sector by $0.14 \%$. Market capitalization of Bahraini public shareholding companies listed on the bourse increased to BD 6.96 billion compared to BD 5.86 billion at the beginning of the year. Table 1 summarizes the main performance of the Bahrain Bourse from year 2004 till the second quarter of 2013.

Table 1. The main performance of the Bahrain Bourse

\begin{tabular}{llllll}
\hline Year & $\begin{array}{l}\text { BAH All } \\
\text { Share Index }\end{array}$ & $\begin{array}{l}\text { Market Capitalization } \\
(\mathrm{ml} \mathrm{BD})\end{array}$ & $\begin{array}{l}\text { Value of Shares } \\
\text { Traded (ml BD) }\end{array}$ & $\begin{array}{l}\text { Volume of Shares } \\
\text { Traded (ml) }\end{array}$ & $\begin{array}{l}\text { No. of } \\
\text { Transaction }\end{array}$ \\
\hline $2013(\mathrm{Q} 2)$ & $1,187.79$ & 6,547 & 96.54 & 881.59 & 4,358 \\
2012 & $1,065.61$ & 5,856 & 110.24 & 627.71 & 10,168 \\
2011 & $1,143.69$ & 6,254 & 104.97 & 520.22 & 11,818 \\
2010 & $1,432.26$ & 7,563 & 108.4 & 612.2 & 19,647 \\
2009 & $1,458.24$ & 6,131 & 178.4 & 852.2 & 30,317 \\
2008 & $1,804.07$ & 7,520 & 787.3 & 1675.8 & 43,540 \\
2007 & $2,755.27$ & 10,185 & 403.1 & 851.1 & 27,707 \\
2006 & $2,217.58$ & 7,963 & 522.9 & 727.6 & 21,699 \\
2005 & $2,195.80$ & 6,547 & 268.1 & 458.3 & 22,463 \\
2004 & $1,773.65$ & 5,105 & 174.6 & 336.5 & 15,744 \\
\hline
\end{tabular}

Source: The Bahrain Bourse Website 2014. 
With the development of the bourse, government institutions and companies started issuing several investment instruments taking advantage of the legislative and technical infrastructure established by the bourse. Since then, the bourse witnessed the listing and registration of preferred shares, bonds, sukuk (Islamic bonds), and mutual funds, making it the first bourse to list such instruments in the region.

\section{Previous Studies}

Past literature studied weak-form efficiency in the Bahrain market and the Gulf region supported the random walk hypothesis of share prices and concluded that such stock markets are informationaly efficient in the weak-form, (Al-Loughani, 1995; Rao \& Shankarajah, 2003; Asiri, 2008; Asiri \& Alzeera, 2012). Moving from the first level of weak form efficiency to the second level of semi-strong efficiency, dividend announcement is used to test Bahrain market. The reason for testing dividend announcement is that in finance literature, one of the greatest puzzles over the past several decades has been dividend policy. This was argued by Chen et al. (2009), where they assessed reactions in the Chinese market to dividend fluctuations and found that regardless of whether they are increases or decreases, cash dividends are viewed in a positive light, and welcomed as assets.

Gordon (1959) developed a dividend model which introduced the notion that dividend payment augmentation should display a direct correlation to a firm's value increase. However, Miller's and Modigliani's (1961) dividend irrelevance theory counters that idea, claiming that neither current nor future dividend decisions bear any influence on the value of a firm. Their conclusion named the net profits and investments of a firm to be the most significant factors in determining a firm's ultimate value under ideal economic circumstance. Thus, Miller and Modigliani asserted that dividend policy has no relevance in determining the value of a firm. Yet their theory has not deterred many researchers from continuing to explore the effects of dividend policy, and these researchers have proposed four major explanations in defense of dividend relevance: the bird-in-the-hand theory, signaling, tax preference, and agency explanations. They further argued that in an economic utopia, where no companies or shareholders were subjected to taxes or fiscal restrictions, dividend payments would have zero impact on the ultimate value of shareholders. But this is not likely to be a reality; the field still demanded a strong economic argument to explain the general preference most investors displayed for dividend income, which Graham and Dodd (1951) subsequently provided. Walter (1956) and Gordon (1959 and 1962) built upon the work of Graham and Dodd by advancing the concept of dividend relevancy, an idea that has since been formalized into a theory, and which suggests that current stock prices accurately reflect the current value of all expected future dividend payments.

The bird-in-the-hand theory juxtaposes dividends with capital gains, and from this vantage point concludes that a relationship does, indeed, exist between a firm's value and dividend payouts due to the fact that dividends promise shareholders a great deal more certainty than capital gains (Robinson, 2006). Earlier, Gordon (1959) and Lintner (1956) examined this relationship, and developed the assumption that rate of return would decrease in direct ratio to any increase in payout. This perspective suggests that investors should be concerned about suffering losses in capital gains any time a firm increases its payout ratio. From this inference, both Gordon and Lintner concluded cash dividends were more favorable to shareholders than capital gains, and suggested that shareholders should keep this in mind when making any stock-related decisions. Miller and Rock (1985) offered a different perspective still by deeming dividends as signals whose function is to manage any asymmetry that may exist in the information shared between managers and shareholders. Robinson (2006) proposed that management actively use change in dividend as a signaling tool intended mainly to reduce instances of asymmetrical information sharing. This school of thought was contested by Black (1976) and Ambarish et al. (1987), who brought evidence suggesting an irremediable uncertainty in determining whether or not dividends could actually provide accurate and coherent signals about a firm's expected returns. On the other hand, Gordon and Bradford (1980) suggested that more elite shareholders might actually favor dividends to capital gains on the grounds that dividends result in direct cash flow, while capital gains offer little or no tax advantage in the long run. Robinson (2006) disagreed, pointing to the immediate tax liability that dividends create for shareholders, which would lead any rational shareholder to favor lower dividends.

The work of McCluskey et al. (2006) supports the conclusion that the market reaction on dividend announcement days is not only statistically relevant but significant. Research has been done by Hamid Uddin and Osman (2008) on the effect of dividend payments in non-tax countries, such as the Kingdom of Saudi Arabia, and the evidence suggests that in such cases, dividend payments have little to no impact on shareholders' value and do not provide any positive signals indicating potential increase of cash flow in the future. In addition, their research found that despite the lack of positive signals, dividend decreases predict a lack of cash flow in the future; it can thus be inferred that if dividend income is taxable, investors would prefer to avoid increasing their tax liability and opt for fewer dividends. Beyond that, they suggested that given the caliber of such investors' 
clientele, it may be preferable for corporations to indicate that the money in question is free flow cash by distributing the surplus to investors. On the contrary, Al-Yahyaee et al. (2011), whose research focused on the Omani market, which is also a non-tax nation, discovered a direct, correlative relationship between announcements of dividend increases and increased stock prices and announcements of dividend decreases and plummeting stock prices. The research also encompassed date from firms that did not change their dividends and discovered that their negative returns were relatively minor. Asiri and Taleb (2012) analyzed the reaction of the Bahrain Bourse to dividend announcements for the period of 2006 to 2011. The results revealed that on average, Bahraini investors gained $2.6 \%$ in abnormal returns due to dividend announcements. The study then deconstructed these announcements into specific areas for further analysis: Dividend increases, dividend decreases, dividend stable and dividend initiating. The findings support the dividend relevance theory that states abnormal returns increase in conjunction with dividend increases and decrease in conjunction with dividend decrease announcements.

While the work of numerous researchers, including Ogden (1994) and Lee (1995), has established a noteworthy positive relationship between stock price and dividend payments, the research of Easton and Sinclair (1989) concluded that the relationship was negative. The work of Bar-Yosef and Huffman (1986) introduced evidence suggestive of a negative relationship between dividend announcement and stock returns, which they attributed to tax effect; however, their work also recognized the significance of the tax effect's impact, which they found resulted in a positive relationship between stock returns and dividend announcements. Pettit's research (1972) found the earning performance to be a negligible factor in that it bore no significant impact on price increases or drops; regardless of whether the earning performance was high or low, the research revealed a consistent correlation between significant price increase after announcements of dividend increases, and a significant price drop following the announcement of cash dividend decreases. Similarly, Aharony and Swary (1980) focused on the length of time that these effects manifest a significant influence and found that during the twenty days surrounding the announcement of either cash dividend increases or decreases, investors reported abnormal returns on both the positive and negative ends of the spectrum. Suwanna (2012) tested the impact of dividend announcement on the return of the Stock Exchange of Thailand, and the results confirmed the signaling theory in finding that dividend announcements have a significant impact on share prices.

Easterbrook's (1984) argument is that one cannot assume that managers will act in the best interests of owners, resulting in many shareholders taking action and paying others to monitor managers' behavior, thereby incurring unwieldy agency costs. The agency theory discussed by Jensen and Meckling (1976) and Rozeff (1982) explicates the belief that shareholders and creditors prioritize different interests. According to this theory, shareholders generally seek out large dividend payments, while it is in the best interest of creditors to restrict payouts in order to maximize the amount of firm resources available to repay their claims. Rozeff (1982) evidenced a negative correlation between dividend payouts and insider representation, while Crutchley and Hansen (1989) suggested that, in attempt to control agency costs, managers often opt to pay dividends. Jensen's contribution (1986) to the discussion is the free cash flow overinvestment hypothesis, which accuses managers of prioritizing their own interests by saving cash so they can invest in negative net present value projects, despite the fact that such investments escalate agency expenditure and decrease the overall value and wealth of a firm. This opinion is maintained by Allen and Michaely (2003), and it insinuates that dividend policy change and stock price reaction are moving in a parallel direction, and have a direct, positive correlation. Grullon et al. (2002) found that firms tend to respond to declining investment opportunities by increasing dividends, and Lie (2000) proposed the idea that firms that chose to increase dividends did so because they had more available cash than their industry peers. Borokhovich et al. (2005) analyzed how a firm's personnel affected returns, and discovered that, each time they announced sizeable dividend increases, firms with more non-executive directors experienced more positive returns.

Pettit (1972), Ghosh and Woolridge (1991) and Abeyratna et al. (1996) argued that dividend increases are indicative of propitious change in the market, while dividend cuts tend to predict poor future performance and stunt the free flow of cash. Asquith and Mullins (1983) and Michaely et al (1995) similarly concluded that stock prices exhibit positive spikes when dividend initiations occur, and react poorly to dividend decreases. However, other research presents evidence to the contrary. According to Woolridge and Ghosh (1985), Soter et al. (1996) and Johnson and Jensen (1997), dividend decreases are predictive of positive signifiers, as they stand as proof that a firm is accumulating funds with the goal of financing a variety of profitable investments. They bolstered their argument with the claim that excessive cash disbursement depletes funds due to the high transaction costs of issuing new shares. From this they drew the conclusion that dividend reduction is a significant and progressive turning point for the firm; when they reviewed profitability rates, cash balances, current asset levels, 
sales figures and debt ratios from the period directly following the dividend cut, their sample showed significant improvement across the board.

Fama and Babiak (1968), whose studies centered on the role of determinants in dividend payments, asserted that net income was a far superior measure of dividend than cash flow. Yet Farrelly et al. (1986) drew a conflicting conclusion, deeming the patterns found in past dividends obsolete, and anticipated future earnings to be the most accurate determinants of dividend payments. Pruitt and Gitman (1991) recognized the importance of both past and present profit analysis in determining the most significant forces to impact dividend payments and suggested that firms should look to risk variability in earnings when devising dividend policies. Finally, Bolbol and Omran (2005) analyzed the issue through a cultural lens, and discovered that Arab firms tend to have high payout ratios. Further assessment attributed these high ratios to three factors: (1) most Arab countries, including Bahrain, have minimal or no dividend taxes; (2) investors in Arab markets exhibit a preference for periodical income disbursed over regulated time periods, which results in high payouts that allow investors to maintain consistent activity in the stock market; and (3) stakeholders interpret high payouts as positive signals that promise easy access to external funds.

In measuring the abnormal returns, Kothari and Warner (1997) used four different models: 1) The market-adjusted return model, 2) the market model, 3) the capiital assets pricing model (CAPM) and 4) the Fama-French three factor model. Meanwhile, Brown and Warner (1985) used the following three approaches: 1) Mean-adjusted return, 2) market-adjusted return, 3) ordinary leaset square (OLS) market model.

Based on the above reviewed literature, four null hypotheses were developed as follows:

$\mathrm{H}_{1}$ : Dividend announcements have no effect on the market value of a firm.

$\mathrm{H}_{2}$ : There is no significant difference between announcements of dividend increases and dividend decreases.

$\mathrm{H}_{3}$ : Investors' reactions to dividend announcements are the same across all the sectors.

$\mathrm{H}_{4}$ : There is no significant difference between market adjusted and risk-adjusted abnormal returns.

However, the reason behind testing $\mathrm{H}_{4}$ is that the Bahrain Bourse and some other stock exchanges do not provide betas for the securities, i.e. market risk. However most researchers used the OLS regression model to estimate betas, which is an estimation rather than an accurate measure. Hypothesis four $\left(\mathrm{H}_{4}\right)$ then will clarify if there is any significant difference between these two measures.

\section{Data and Methodology}

Forty Bahraini companies were drawn from all listed companies in the Bahrain Bourse (see Appendix 1). The study chose to limit its focus to the Bahraini companies for the sake of clarity and simplicity, as non-Bahraini companies are subject to different rules and requirements. Cash dividend announcements ranging from January 2004 to December 2013 were analyzed, and of 191 such announcements, 157 were deemed appropriate in that they included only one announcement and offered sufficient information regarding company stock prices. In addition, the announcement must not have overlapped into the 60-day period of the following announcement. Event study was applied to this data to determine the effect of dividend announcements on stock returns.

When measured, stock returns fall into one of three categories: "actual", "expected" and "abnormal". Abnormal returns (AR) are determined by a formula in which the actual return for firm $i$ is represented by $R_{i}$, and the market return at during that period is signified by $R_{m t}$. For reliable and accurate results, and as explained earlier in hypothesis four, two formulas are used to measure the abnormal returns: One is named market-adjusted abnormal returns (formula number 1) and the other one is named risk-adjusted abnormal returns, (formula number 2). The first formula measures the daily change in a security's price in relation to the corresponding change in the market index that result from dividend announcements. Therefore, to determine the abnormal returns, the formula is as follows for firm $i$ for period $t$ :

$$
A R_{i t}=R_{i t}-R_{m t}
$$

However, for the second formula, since the Bahrain Bourse does not supply the necessary beta coefficients to encompass risk-adjustment for the returns employed, regression is used to estimate the parameters (the constant and the slope). The slope coefficient represents the beta and is used to calculate the risk-adjusted abnormal returns. Ryan et al. (2000) used 90 two-day periods from $t=-261$ to $t=-82$ to estimate the market model parameters. They used CRSP equally weighted index as the market proxy. Suwanna (2012) estimated the return parameters by defining an estimation window period of 100 days starting from $t=-120$ to $t=-21$ days before the event day (Day 0). Using CAPM, the expected daily return $E\left(R_{i t}\right)$ for stock $i$ on day $t$ was calculated. Videen (2010) used the estimation window period of 200 days ending 50 days before the event date. He used regression 
to estimate the coefficients for the CAPM. For this study, parameters $(\alpha$ and $\beta$ ) are estimated using a time period of 90 days, i.e. -120 day to -31 day before the announcement day. Moreover, CAPM is used for the expected return $E\left(R_{i t}\right)$ for firm $i$ at time $t$ as follows:

$$
E\left(R_{i t}\right)=\alpha_{i}+\beta_{i} * R_{m t}
$$

Where $\alpha_{i}$ and $\beta_{i}$ are OLS estimators from the 90 days estimation period and $R_{m t}$ is the daily market return.

The abnormal returns in this study will be determined by calculating the difference between the actual return and the expected return. The results derived from the two formulas presented above will be compared, and any significant differences will be noted. For the rest of the analysis, market-adjusted return will be used. Once abnormal returns are determined for firm $i$ in time $t$, cumulative abnormal returns (CAR) are calculated using the paradigm favored by Asiri and Talib (2012), which is built on Suwanna (2012), Al Yahyaee et al. (2011), Hamid Uddin and Osman (2008), and Hamid Uddin (2003). Fama et al. (1969) employed the CAR formula, which measures the total cumulative return within the same 60-day window, wherein the announcement of cash dividends is deemed as Day 0. This structure was used in this study to examine dates falling within a 60-day window on either side of the announcement, in which the announcement is Day 0 , and the thirty days preceding $(-30)$ and thirty days following (+30) Day 0 have been taken into account. Cumulative average abnormal returns $(C A A R)$ then is calculated using the formula as follows:

$$
C A A R_{t}=\frac{1}{N} \sum_{t=1}^{N} C A R_{t}
$$

To check whether these AAR and CAAR are significantly different from zero or not, Mandal and Rao (2010) used cross sectional t-test as follows:

$$
t=\frac{A A R_{t}}{s_{t} / \sqrt{n}}
$$

Where $\mathrm{n}$ is the number of the events and $\mathrm{s}_{\mathrm{t}}$ is the cross sectional standard deviation of abnormal returns at period $t$ and is computed as follows:

\section{Findings and Discussion}

$$
S_{t}=\sqrt{\frac{1}{n-1} \sum_{i=1}^{n}\left(A R_{i t}-A A R_{t}\right)^{2}}
$$

Using market-adjusted return, Table 2 highlights that the $A A R$ on the day of the announcement is only $0.5 \%$, which would be considered insignificant by most, although when compared to other $A A R s$ within the same time frame, it stands out. Statistically it is found to be highly significant at 5\% (t-value $=2.449$ ). Tracking the progress of $A A R$, a positive abnormal return becomes evident. For instance, on day -1 , the abnormal return is 0 ; it then spikes to $0.5 \%$ on Day 0 and drops only slightly to $0.30 \%$ on day +1 . Furthermore, days succeeding the announcement reveal consistently positive returns, with the exception of few days of zero return. Looking beyond day +20 and forward to day +30 , the variance in $A A R$ was seemingly random, and although it generated largely negative returns, it was deemed to be statistically insignificant. From this evidence, it is reasonable to infer that the only significant market reaction occurs on the day of the dividend announcement itself. The fluctuation in $A A R$ results documented in the Bahrain Bourse did not, generally, exhibit any significant changes in relation to dividend announcements. The most noteworthy statistic of the entire period occurred on the announcement day itself, when the maximum $0.5 \%$ was reached. Figure 1 reveals inconsistent fluctuation in $A A R$ 's results from the day -15 to +15 , although there is evidence of a definite positive trend occurring within the first 19 days succeeding the announcement (as shown in Table 2). From day +20 and onward, these numbers plummet sharply, and the percentages remain negative for the rest of the period. 


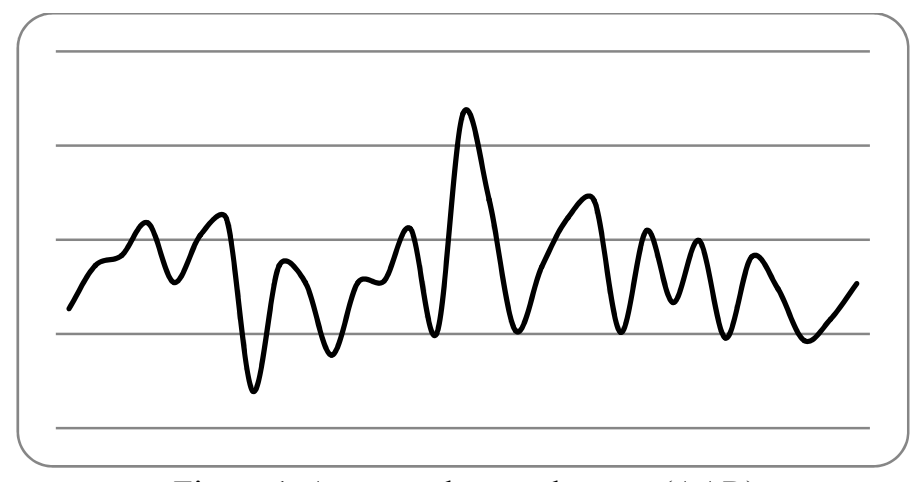

Figure 1. Average abnormal return (AAR)

The analysis of the cumulative abnormal returns provided by Table 2 reveals that investors did, indeed, experience gains from dividend announcements within the same 60-day time frame. The CAAR performed poorly from day -30 through day -15 , with percentages stuck in the negative range. However, the negative $C A A R$ got smaller until it reached zero on day -10 . But as Day 0 neared, the evidence illustrates a consistent rise in the CAAR. Percentages rose from $0 \%$ on day -10 to $1.30 \%$ on Day 0 . This positive trend continued for the next 30 days, peaking on day +19 at $3.46 \%$. The percentages subsequently dropped, and were down to $2.29 \%$ by day +30 . The behavioral attitudes of investors that can be inferred from these results are that investors lacked confidence prior to the dividend announcement, increased activity in the anticipatory week prior to the announcement, and then overreacted for the three weeks following the announcement.

Figure 2 supports these assumptions, illustrating a loss in market value in the days preceding the announcement, followed by a spike in the value of cash dividends received that was significant enough to redeem the value lost prior to the announcement. When subjected to a t-test, the daily $C A A R$ from day -4 to day +30 proved to be statistically significant at less than $1 \%$. Thus, pieced together and viewed as a whole, this data illuminates significant positive abnormal returns during and around dividend announcement, and reveals a positive attitude in Bahraini investors toward cash dividends.

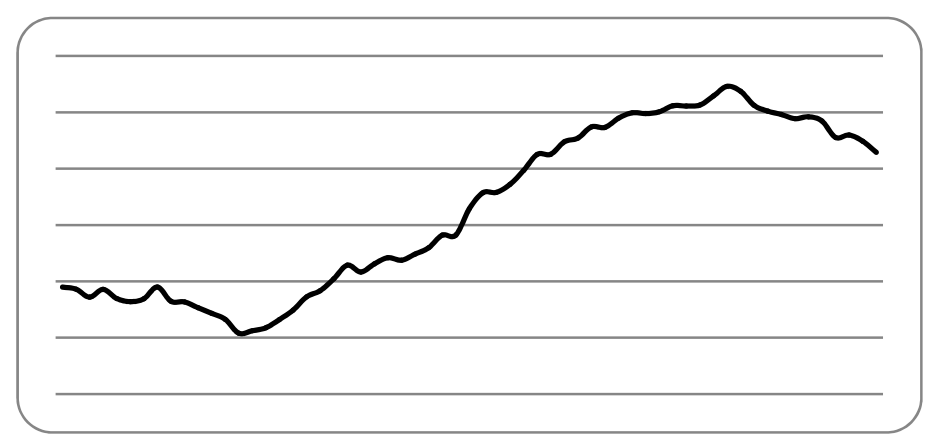

Figure 2. Market-adjusted cumulative average abnormal returns (CAAR)

Now, comparing the distribution of $C A A R$ for the market-adjusted with the risk-adjusted returns, Figure 3 shows that both have similar patterns, but risk-adjusted returns take the $C A A R$ back to a negative on day +30 after the announcement. Table 3 compares the risk-adjusted returns and market-adjusted returns that occurred within the 60-day window. Observing the ten days preceding and succeding Day 0, it is evident that the risk-adjusted returns started with negative $C A A R$, but moved into postive territory on Day 0 and remained postive for the following ten days. The market-adjusted return started on day -10 with a small positive $C A A R$, which increased through Day 0 and ended with $2.7 \%$ on day +10 . Using the Wilcoxon signed rank test, the results indicate that the null hypothesis $\left(\mathrm{H}_{4}\right)$ of the no difference between the two distirbution is rejected at $1 \%$ level of significance. Since the distributions in Figure 3 show similar patterns, it may be inferred that using either formula points to similarities in the behaviour of the market, with minor differences in the rate of the abnormal returns. 


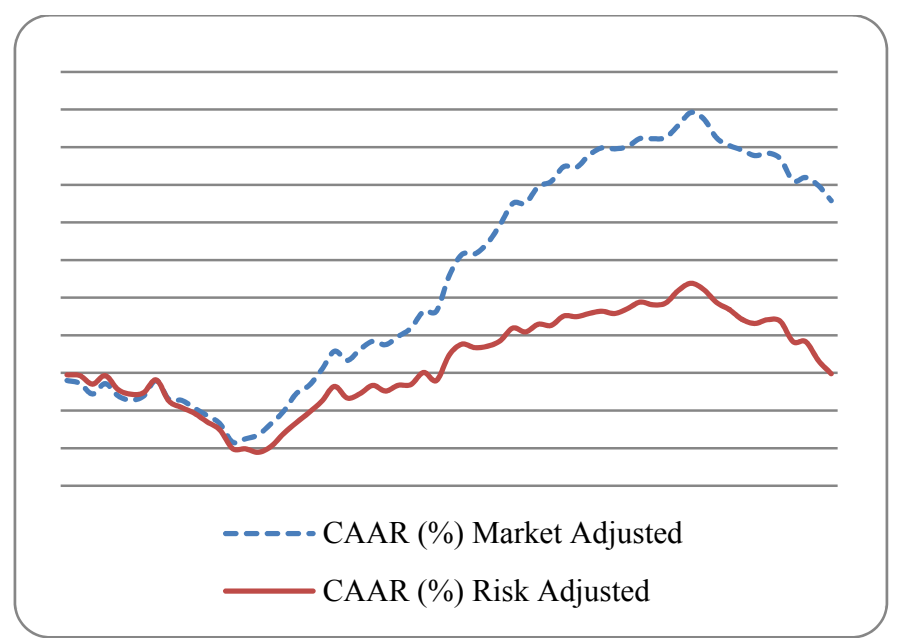

Figure 3. Risk-adjusted v. market-adjusted CAAR

Table 2. Market-adjusted abnormal returns

\begin{tabular}{|c|c|c|c|}
\hline Day & $\begin{array}{l}\text { Total Abnormal Return } \\
\text { Total } A R\end{array}$ & $\begin{array}{l}\text { Average Abnormal Return } \\
A A R\end{array}$ & $\begin{array}{l}\text { Cumulative Abnormal Return } \\
\text { CAAR }\end{array}$ \\
\hline-30 & -.1560 & -.0010 & -.0010 \\
\hline-25 & -.0850 & -.0010 & $-.0040 *$ \\
\hline-20 & -.1600 & -.0010 & $-.0050 * * *$ \\
\hline-15 & .0830 & .0010 & $-.0080 * * *$ \\
\hline-10 & .3230 & .0020 & .0000 \\
\hline-9 & .3760 & $.0020^{*}$ & .0030 \\
\hline-8 & -.1870 & -.0010 & .0020 \\
\hline-7 & .2230 & .0010 & $.0030 *$ \\
\hline-6 & .1680 & .0010 & $.0040 * *$ \\
\hline-5 & -.0690 & .0000 & $.0040 * *$ \\
\hline-4 & .1680 & .0010 & $.0050^{* * *}$ \\
\hline-3 & .1730 & .0010 & $.0060 * * *$ \\
\hline-2 & .3440 & $.0020^{* *}$ & $.0080 * * *$ \\
\hline-1 & .0010 & .0000 & $.0080^{* * *}$ \\
\hline $\mathbf{0}$ & .7200 & $.0050 * * *$ & $.0130 * * *$ \\
\hline+1 & .4390 & .0030 & $.0160 * * *$ \\
\hline+2 & .0110 & .0000 & $.0160 * * *$ \\
\hline+3 & .2190 & .0010 & $.0170^{* * *}$ \\
\hline+4 & .3800 & $.0020^{* * *}$ & $.0200 * * *$ \\
\hline+5 & .4360 & $.0030^{* *}$ & $.0230 * * *$ \\
\hline+6 & .0060 & .0000 & $.0230 * * *$ \\
\hline+7 & .3380 & $.0020^{* *}$ & $.0250 * * *$ \\
\hline+8 & .1030 & .0010 & $.0250 * * *$ \\
\hline+9 & .3050 & .0020 & $.0270^{* * *}$ \\
\hline+10 & -.0130 & .0000 & $.0270^{* * *}$ \\
\hline+15 & .1650 & .0010 & $.0310 * * *$ \\
\hline+20 & -.1350 & -.0010 & $.0340 * * *$ \\
\hline+25 & .0510 & .0000 & $.0290 * * *$ \\
\hline+30 & -.3050 & -.0020 & $.0230^{* * *}$ \\
\hline
\end{tabular}

Note. $* * * 1 \%, * * 5 \%, * 10 \%$ level of significance. 
Table 3. Risk-adjusted (R) v. Market-adjusted (M) CAAR

\begin{tabular}{|c|c|c|c|c|}
\hline Day & AAR-Risk-adjusted & CAAR-R $(\%)$ & AAR-Market-adjusted & CAAR-M (\%) \\
\hline-30 & -.0003 & -.0266 & -.0010 & -0.1013 \\
\hline-25 & -.0006 & -.2829 & -.0006 & -0.3598 \\
\hline-10 & .0015 & -.3767 & .0021 & 0.0436 \\
\hline-9 & .0020 & -.1799 & $.0024 * *$ & 0.2877 \\
\hline-8 & -.0015 & -.3339 & -.0012 & 0.1660 \\
\hline-7 & .0006 & -.2768 & .0014 & 0.3109 \\
\hline-6 & .0011 & -.1656 & .0011 & 0.4200 \\
\hline-5 & -.0008 & -.2409 & -.0005 & 0.3750 \\
\hline-4 & .0008 & -.1646 & .0011 & 0.4839 \\
\hline-3 & .0001 & -.1546 & .0011 & 0.5964 \\
\hline-2 & .0016 & .0062 & $.0022 * *$ & 0.8199 \\
\hline-1 & -.0011 & -.1015 & .0000 & 0.8208 \\
\hline 0 & $.0034 * *$ & .2362 & $.0047 * * *$ & 1.2881 \\
\hline+1 & .0015 & .3821 & .0028 & 1.5730 \\
\hline+2 & -.0005 & .3362 & .0001 & 1.5803 \\
\hline+3 & .0002 & .3541 & .0014 & 1.7224 \\
\hline+4 & .0007 & .4266 & $.0025 * *$ & 1.9693 \\
\hline+5 & .0017 & .5960 & $.0028 * *$ & 2.2527 \\
\hline+6 & -.0005 & .5444 & .0000 & 2.2563 \\
\hline+7 & .0010 & .6466 & $.0022 *$ & 2.4761 \\
\hline+8 & -.0002 & .6307 & .0007 & 2.5428 \\
\hline+9 & .0012 & .7557 & .0020 & 2.7408 \\
\hline+10 & -.0001 & .7470 & -.0001 & 2.7321 \\
\hline+20 & -.0008 & 1.1057 & -.0009 & 3.3735 \\
\hline+30 & -.0017 & -.0116 & -.0020 & 2.2894 \\
\hline
\end{tabular}

Note. $* * * 1 \%, * * 5 \%, * 10 \%$ level of significance.

Further investigation of the effects of dividend information was attempted through analysis of different dividend policies. Dividend announcements were categorized into two groups: Dividend increase and dividend decrease. The results presented in Table 4 can be compared to the results of the previous year to reveal that dividend increase manifested in relation to 46 announcements and dividend decrease manifested in response to 31 announcements. Day 0 shows that announcement of dividend increase generated $0.41 \%$ abnormal returns while dividend decrease produced a negative $-0.34 \%$. The day +30 CAAR were statistically significant for both categories of dividends. The results were as follows: $0.45 \%$ for dividend increasing stocks and $0.35 \%$ for the dividend decreasing stocks. A comparison of dividend increases to dividend decreases reveals that, on average, investors gained a substantially higher return on increasing dividend stocks, and a pattern of increased return is also evident in increasing dividends when compared to results from the previous declaration. A deeper analysis of how differing dividend policies affect dividend information and the behavior of CAAR is presented in Figures 4 and 5.

Figure 4 represents 46 dividend increasing announcements for stocks that registered positive CAAR from day -4 to the peak, which occurred on day +21 when the $C A A R$ stood at $1.27 \%$. The $C A A R$ slowly and steadily declined from the peak day until day +30 , which was $0.45 \%$. There is evidence of a slight decrease on day +1 and day +3 , but after that, the percentages return to a steady increase. What might account for this behavior? One hypothesis is that investors entertain a temporary confidence that stocks offering a dividend increase contain the promise of significant fiscal growth in the future. However, this positive effect cannot and does not sustain, slowly decreasing only to flat-line at a normal level before the dividend announcement and once again after day +30 . This outlook suggests that market overreaction and profit booking by active short-term traders are key factors in determining the impact of the announcements on the market. Thus, it can be concluded that dividend increases incite a positive ripple effect and are successful in enticing investors with good returns.

However, when assessing the data presented in Figure 5, which depicts the activity of CAAR in response to the 31 dividend decreasing stocks, a sharp decline can be observed beginning on day -14 and continuing through day -2 , followed by fluctuation and an inability to rise beyond the range of negative percentages through day +5 . 
Temporary increases prevailed through day +10 , after which the $C A A R$ rose into the positive range, where they remained through day +30 . What is most striking is that the dividend decreases register negative returns on Day 0 , reaching just $-0.34 \%$. Positive returns did not emerge until day +6 and +7 and then +10 onward, after which the numbers began to steadily increase through day +30 , reaching $0.35 \%$. This data points to a clear negative reaction amongst investors to the announcement of dividend decreases, which suggests that such decreases actively diminish investors' faith in the companies' future returns.

In sum, the empirical results derived from the analysis of dividend increasing stocks reveal that increases in dividends are generally accompanied by increases in stock prices, and are consistent with the empirical implications of the signaling hypothesis, while the results derived from the investigation of dividend decreasing stocks only partially support the dividend-signaling hypothesis, as they were often accompanied by stock prices moving in the opposite direction, albeit only temporarily. From this it can be inferred that cash dividend announcements create a positive response in the Bahraini investors and drive them to action, regardless of their content. Whether rising or falling, cash dividends are favored in Bahrain.

Table 4. CAAR for increase and decrease dividend announcement

\begin{tabular}{|c|c|c|c|c|c|}
\hline Event Day & $\begin{array}{l}\text { Dividend } \\
\text { Increase }(\mathrm{N}=46)\end{array}$ & $\begin{array}{l}\text { Dividend } \\
\text { Decrease }(\mathrm{N}=31)\end{array}$ & Event Day & $\begin{array}{l}\text { Dividend } \\
\text { Increase }(\mathrm{N}=46)\end{array}$ & $\begin{array}{l}\text { Dividend } \\
\text { Decrease }(\mathrm{N}=31)\end{array}$ \\
\hline-30 & -0.0290 & -0.0700 & $\mathbf{0}$ & $0.4100 * * *$ & $-0.3400 * * *$ \\
\hline-20 & $-0.0487 * *$ & $-0.0600 *$ & 1 & $0.3900 * * *$ & $-0.2600 * * *$ \\
\hline-15 & $-0.2412 * *$ & $-0.6200 * * *$ & 2 & $0.4100^{* *}$ & $-0.3200 * * *$ \\
\hline-14 & $-0.2800 * * *$ & $-0.7200 * * *$ & 3 & $0.3800 * * *$ & $-0.3400 * * *$ \\
\hline-13 & $-0.2900 * * *$ & $-0.4100 * * *$ & 4 & $0.4100 * *$ & $-0.2400 * * *$ \\
\hline-12 & $-0.2900 * * *$ & $-0.4500 * *$ & 5 & $0.4400 * *$ & $-0.3200 * *$ \\
\hline-11 & $-0.3200 * * *$ & $-0.3500 * * *$ & 6 & $0.7000^{* * *}$ & 0.0400 \\
\hline-10 & $-0.2500 * * *$ & $-0.3500 * * *$ & 7 & $0.7200 * * *$ & 0.0900 \\
\hline-9 & $-0.1200 * * *$ & $-0.5500 * * *$ & 8 & $0.8300 * * *$ & -0.0600 \\
\hline-8 & $-0.1700 * * *$ & $-0.6000 * * *$ & 9 & $0.9900 * *$ & -0.0900 \\
\hline-7 & $-0.0900 *$ & $-0.6600 * *$ & 10 & $1.0300 * *$ & 0.0700 \\
\hline-6 & -0.0200 & $-0.7200 * * *$ & 11 & $1.3200 * *$ & $0.2100 * *$ \\
\hline-5 & $-0.0300^{*}$ & $-0.7900 * * *$ & 12 & $1.4100^{* *}$ & $0.2500 * *$ \\
\hline-4 & $0.0800 *$ & $-0.8000 * * *$ & 13 & $1.3200^{* *}$ & 0.0900 \\
\hline-3 & $0.1200 * *$ & $-0.8000 * * *$ & 14 & $1.1100^{* * *}$ & 0.0900 \\
\hline-2 & $0.1600 * * *$ & $-0.8300 * * *$ & 15 & $1.2100 * * *$ & $0.1900 * *$ \\
\hline-1 & $0.1800 * * *$ & $-0.5200 * *$ & 20 & $1.1100 * * *$ & $0.4100 * *$ \\
\hline $\mathbf{0}$ & $0.4100 * * *$ & $-0.3400 * * *$ & 30 & $0.4500^{* * *}$ & $0.3500 * * *$ \\
\hline
\end{tabular}

Note. $* * * 1 \%, * * 5 \%, * 10 \%$ level of significance.

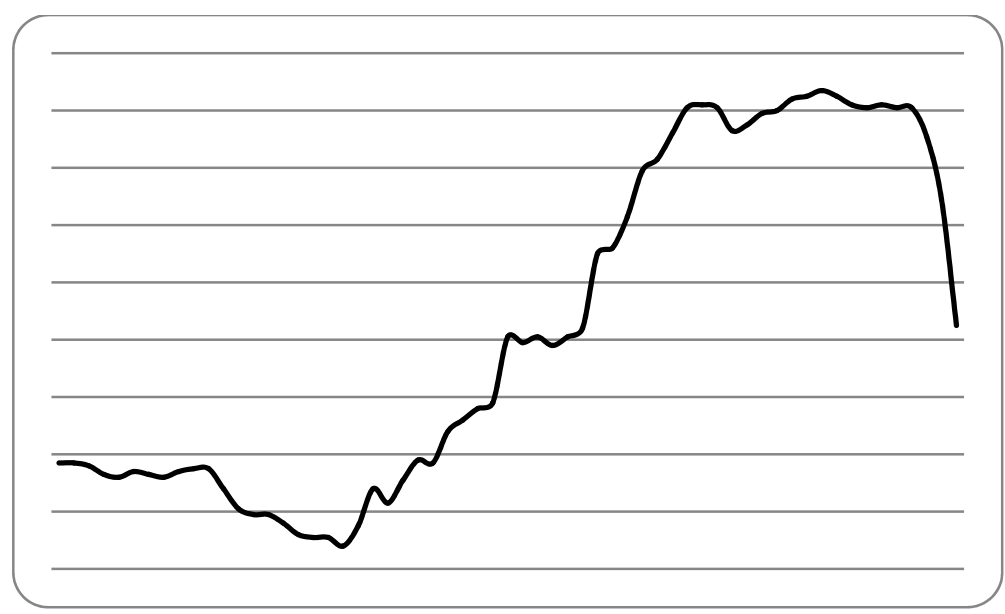

Figure 4. $C A A R$ of dividend increasing stocks 


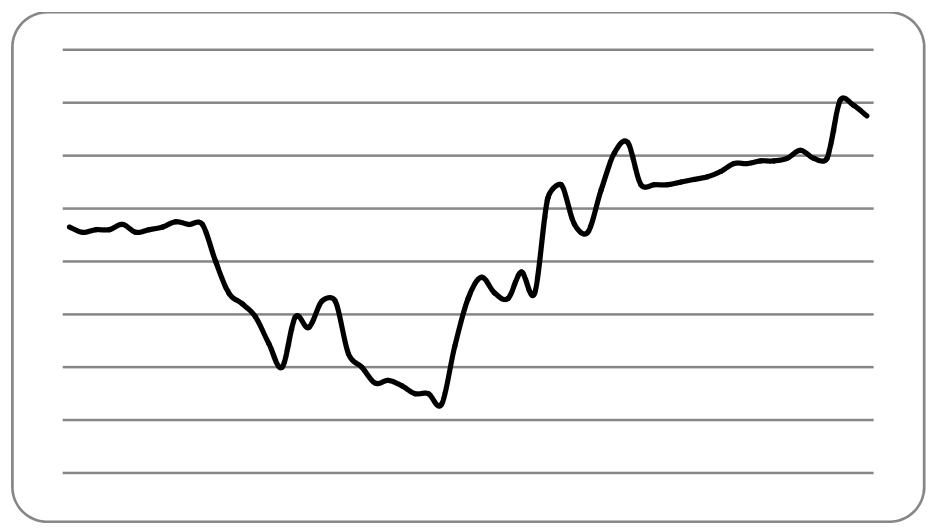

Figure 5. CAAR of dividend decreasing stocks

A final analysis was done to observe any significant differences among the sectors present in the sample of this study. Table 5 and Figure 6 highlight the comparative behavior of $C A A R$ for each sector over the 60-day window. The number of companies in each sector is reported in the table in parentheses. The charts show that almost all the sectors' reactions to the dividend announcements were positive, with the exception of the industrial sector, which shows a negative reaction. However, the industrial sector is composed of only three companies, and accounts for just 12 announcements. One explanation could be that investors in the industrial sector prefer retained earnings to cash dividends. They might be long-term investors and any reduction in retained earnings could indicate a reduction in future investments and future cash flows.

Table 5. Sector analysis

\begin{tabular}{|c|c|c|c|c|c|c|c|c|c|c|c|}
\hline \multirow{3}{*}{ Day } & \multicolumn{2}{|c|}{$\begin{array}{l}\text { Banking } \\
(7 \text { banks })\end{array}$} & \multicolumn{2}{|c|}{$\begin{array}{l}\text { Hotels/Tourism } \\
\text { (4 companies) }\end{array}$} & \multicolumn{2}{|c|}{$\begin{array}{l}\text { Industrial } \\
\text { (3 companies) }\end{array}$} & \multirow{2}{*}{$\begin{array}{l}\text { Insurance } \\
\text { (5 companies) } \\
26 \text { announcements }\end{array}$} & \multirow{2}{*}{\multicolumn{2}{|c|}{$\begin{array}{l}\text { Investment } \\
\text { (12 companies) } \\
24 \text { announcements }\end{array}$}} & \multicolumn{2}{|c|}{$\begin{array}{l}\text { Services } \\
\text { (9 companies) }\end{array}$} \\
\hline & \multicolumn{2}{|c|}{25 announcements } & \multicolumn{2}{|c|}{16 announcements } & \multicolumn{2}{|c|}{10 announcements } & & & & 56 anno & uncements \\
\hline & $A A R$ & $C A A R$ & $A A R$ & $C A A R$ & $A A R$ & $C A A R$ & $A A R \quad C A A R$ & $A A R$ & $C A A R$ & $A A R$ & $C A A R$ \\
\hline-30 & .0023 & .0023 & .0004 & .0004 & .0000 & .0000 & $.0021 \quad .0021$ & -.0010 & -.0010 & -.0001 & -.0001 \\
\hline-25 & .0032 & .0000 & -.0010 & $.0041 * * *$ & -.0008 & $-.0035 * *$ & $.0008 .0063 * * *$ & -.0035 & $-.0132 * * *$ & .0008 & $.0025 * * *$ \\
\hline-20 & -.0025 & $-.0059 * *$ & .0014 & .0006 & -.0025 & $-.0061 * * *$ & $-.0004 .0057 * * *$ & .0030 & $-.0153 * * *$ & -.0008 & $.0071 * * *$ \\
\hline-15 & -.0029 & $-.0148 * * *$ & .0010 & $.0018 *$ & .0000 & $-.0061 * * *$ & $.0020 .0052 * * *$ & -.0045 & $-.0367 * * *$ & .0003 & $.0105 * * *$ \\
\hline-10 & -.0042 & $-.0184 * * *$ & -.0002 & -.0004 & .0000 & $-.0125 * * *$ & $.0004 .0061 * * *$ & .0123 & $.0133 * * *$ & .0001 & $.0149 * * *$ \\
\hline-9 & .0031 & $-.0152 * * *$ & .0082 & $.0079 * * *$ & .0000 & $-.0125 * * *$ & $.0000 .0061 * * *$ & .0032 & $.0165 * * *$ & .0004 & $.0154 * * *$ \\
\hline-8 & -.0031 & $-.0183 * * *$ & .0000 & $.0079 * * *$ & .0000 & $-.0125 * * *$ & $-.0019 .0042 * * *$ & -.0011 & $.0154 * * *$ & -.0014 & $.0139 * * *$ \\
\hline-7 & .0024 & $-.0160 * * *$ & .0010 & $.0088 * * *$ & .0008 & $-.0117 * * *$ & $.0011 .0053^{* * *}$ & .0034 & $.0189 * * *$ & -.0009 & $.0130 * * *$ \\
\hline-6 & -.0039 & $-.0199 * * *$ & .0002 & $.0090 * * *$ & .0000 & $-.0117 * * *$ & $.0000 .0053 * * *$ & .0068 & $.0256 * * *$ & .0021 & $.0151 * * *$ \\
\hline-5 & -.0004 & $-.0203 * * *$ & .0052 & $.0142 * * *$ & .0000 & $-.0117 * * *$ & -.0035 .0018 & -.0017 & $.0240 * * *$ & .0011 & $.0162 * * *$ \\
\hline-4 & .0010 & $-.0193 * * *$ & .0000 & $.0142 * * *$ & .0000 & $-.0117 * * *$ & -.0003 .0015 & .0056 & $.0296 * * *$ & -.0007 & $.0155 * * *$ \\
\hline-3 & -.0004 & $-.0197 * * *$ & -.0011 & $.0130 * * *$ & .0000 & $-.0117 * * *$ & -.0007 .0008 & -.0013 & $.0282 * * *$ & .0020 & $.0175 * * *$ \\
\hline-2 & .0051 & $-.0146 * * *$ & .0013 & $.0144 * * *$ & .0000 & $-.0117 * * *$ & .0009.0017 & .0012 & $.0294 * * *$ & .0022 & $.0197 * * *$ \\
\hline-1 & -.0051 & $-.0197 * * *$ & .0000 & $.0144 * * *$ & .0000 & $-.0117 * * *$ & .0009.0026 & -.0012 & $.0282 * * *$ & -.0018 & $.0179 * * *$ \\
\hline $\mathbf{0}$ & .0094 & $-.0104 * * *$ & .0006 & $.0150 * * *$ & -.0077 & $-.0194 * * *$ & $.0077 .0102 * * *$ & .0009 & $.0290 * * *$ & .0031 & $.0210 * * *$ \\
\hline+1 & -.0006 & $-.0109 * * *$ & -.0020 & $.0130 * * *$ & .0047 & $-.0146 * * *$ & $.0068 \quad .0170 * * *$ & .0059 & $.0349 * * *$ & -.0032 & $.0178 * * *$ \\
\hline+2 & -.0026 & $-.0135 * * *$ & .0015 & $.0145 * * *$ & .0000 & $-.0146 * * *$ & $.0003 .0173 * * *$ & .0006 & $.0355 * * *$ & -.0009 & $.0169 * * *$ \\
\hline+3 & -.0041 & $-.0176 * * *$ & .0041 & $.0186 * * *$ & .0000 & $-.0146 * * *$ & $-.0019 .0154 * * *$ & .0025 & $.0380 * * *$ & -.0002 & $.0167 * * *$ \\
\hline+4 & .0015 & $-.0161 * * *$ & .0006 & $.0192 * * *$ & -.0051 & $-.0198 * * *$ & $.0018 .0172 * * *$ & .0032 & $.0412 * * *$ & .0013 & $.0180 * * *$ \\
\hline+5 & .0022 & $-.0138 * * *$ & .0011 & $.0203 * * *$ & .0000 & $-.0198 * * *$ & $.0036 .0208 * * *$ & -.0036 & $.0376 * * *$ & .0036 & $.0216 * * *$ \\
\hline+6 & .0004 & $-.0134 * * *$ & -.0025 & $.0178 * * *$ & -.0044 & $-.0242 * * *$ & $.0054 .0263 * * *$ & -.0007 & $.0369 * * *$ & -.0017 & $.0199 * * *$ \\
\hline+7 & .0013 & $-.0121 * * *$ & .0013 & $.0191 * * *$ & .0000 & $-.0242 * * *$ & $.0004 .0266^{* * *}$ & .0025 & $.0394 * * *$ & .0010 & $.0210 * * *$ \\
\hline+8 & -.0018 & $-.0139 * * *$ & -.0022 & $.0169 * * *$ & .0000 & $-.0242 * * *$ & $.0062 .0328 * * *$ & -.0011 & $.0383 * * *$ & -.0006 & $.0203 * * *$ \\
\hline+9 & .0026 & $-.0113 * * *$ & .0000 & $.0169 * * *$ & .0000 & $-.0242 * * *$ & $-.0003 .0325 * * *$ & .0028 & $.0411 * * *$ & .0011 & $.0214 * * *$ \\
\hline+10 & .0034 & $-.0079 * * *$ & .0021 & $.0190 * * *$ & .0000 & $-.0242 * * *$ & $-.0017 .0308 * * *$ & -.0040 & $.0371 * * *$ & .0008 & $.0222 * * *$ \\
\hline+15 & -.0022 & $-.0004 * * *$ & .0000 & $.0208 * * *$ & .0000 & $-.0242 * * *$ & $.0063 .0378 * * *$ & .0026 & $.0432 * * *$ & -.0005 & $.0234 * * *$ \\
\hline+20 & -.0010 & $.0254 * * *$ & -.0029 & $.0193 * * *$ & .0000 & $-.0319 * * *$ & $.0004 .0387 * * *$ & -.0031 & $.0277 * * *$ & -.0001 & $.0277 * * *$ \\
\hline+25 & .0071 & $.0360 * * *$ & .0000 & $.0141 * * *$ & .0000 & $-.0382 * * *$ & $-.0023 .0319 * * *$ & .0038 & $.0321 * * *$ & -.0005 & $.0223 * * *$ \\
\hline+30 & -.0050 & $.0284 * * *$ & .0000 & $.0095 * * *$ & .0000 & $-.0382 * * *$ & $-.0015 .0285 * * *$ & -.0004 & $.0269 * * *$ & -.0012 & $.0128 * * *$ \\
\hline
\end{tabular}

Note. *** $1 \%, * * 5 \%, * 10 \%$ level of significance. 
Looking at the banking sector, the CAAR are all negative, including those on the announcement day, and investors started generating abnormal returns from day +15 onward. Investors in the investment sector generated positive CAAR from day -14 , ending with $2.69 \%$ on day +30 . Both hotels and insurance companies reacted positively on day -10 and day -3 , respectively, with CAAR of $9.5 \%$, reaching $2.85 \%$ on day +30 .
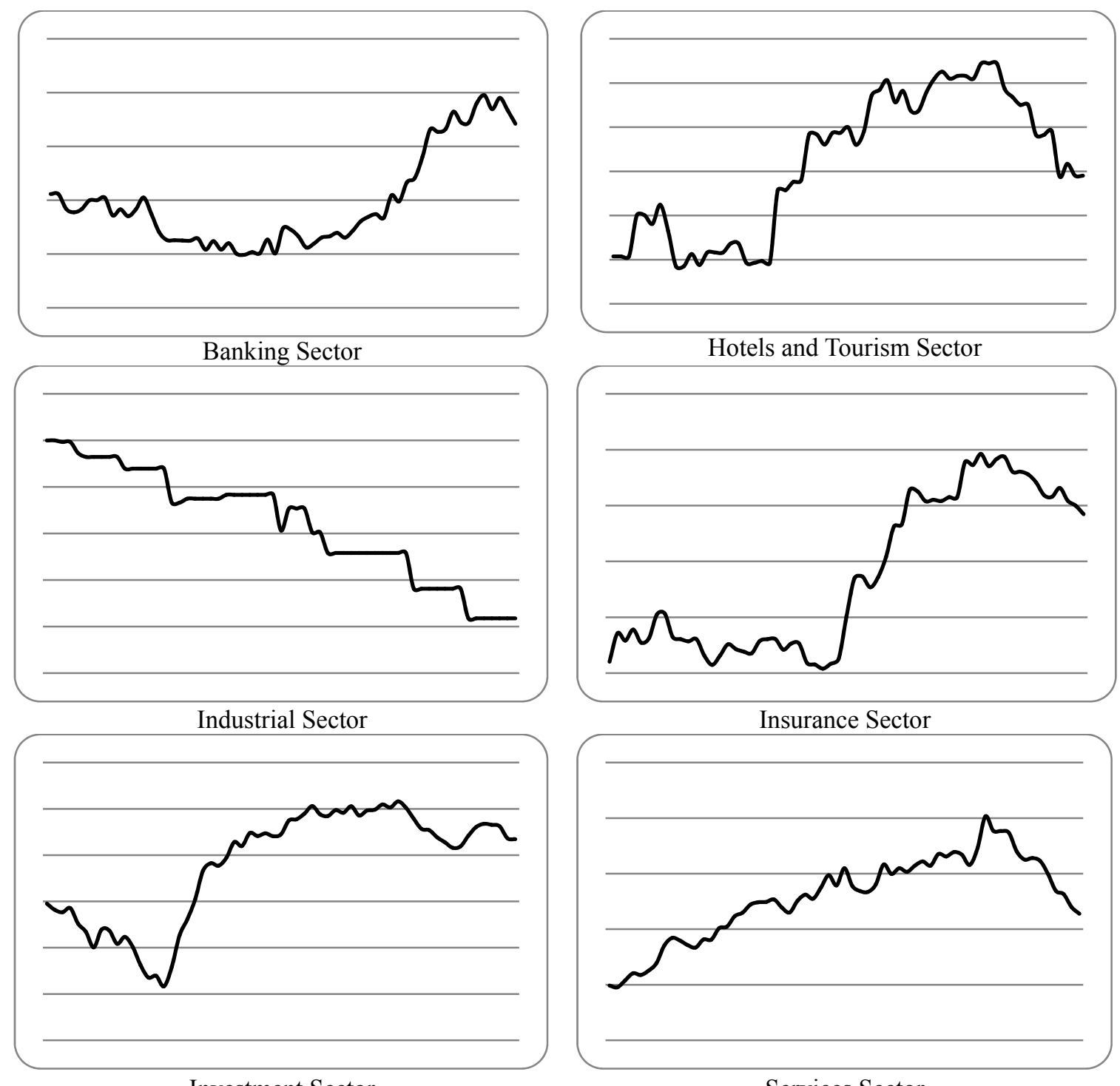

Figure 6. CAAR for sector analysis

\section{Conclusion}

This paper has gathered and examined data that reflects the effects of dividend announcements on stock returns in the Bahrain Bourse. Then, it strives to answer the question of whether dividend announcements could have a significant positive effect in generating abnormal returns, boosting share prices, and attracting investors.

The study's sample looked at a total of 157 dividend announcements representative of market activity reported in the Bahrain Bourse from 2004 to 2013. The data shed a favorable light on the impact of dividend announcements, revealing that investors in the Bahrain Bourse gained approximately $2.3 \%$ in stock returns over the 61 -day period surrounding the announcement day. The behavior of investors was directly influenced by the announcements, and the investors' increased activity in response to the dividend announcements resulted in increased gains. Thus, it can be inferred that dividend announcements do, indeed, transmit prescient information regarding companies' future earnings and cash flow. 
This study then proceeded to examine the data through a different lens, and grouped the announcements for fresh analysis into two categories: dividend increases and dividend decreases payouts. These findings were also overwhelmingly positive in showing increased levels of market activity in direct response to dividend announcements. In the case of the 46 stocks with increasing dividends, investors gained roughly $0.46 \%$ of the market value. Even the 31 stocks that exhibited dividend decreases earned positive returns, with investors gaining $0.35 \%$ of market value on average. Although these dividend decreasing stocks only partially support the dividend-signaling hypothesis, that there is a positive return at all is indicative of an overwhelming positive response to dividend announcements on the part of the Bahraini investors, regardless of the content of these announcements. The announcements are enough in and of themselves to assure investors of a company's overall value as worthwhile investments.

Comparing sectors, the findings of the study confirmed that investors in the Bahrain Bourse are attracted to dividend announcement and this signal is helping them to achieve positive abnormal returns. The time lag might vary from sector to sector, for example, banking sector creates a positive abnormal return from day +12 while hotels and tourisms from day -10 , insurance on day -2 , investment on day -12 and services from day -30 is positive. On the contrary, industrial sector moves downward over all the 61-day of the event period.

The conclusions of this study are contradictory to the findings of Hamid Uddin and Osman (2008) who found that investors do not gain value from dividend announcements in the Saudi Arabian market, which is also a tax-exempt nation. Yet the conclusions drawn by Al-Yahyaee et al. (2011) Suwanna (2012) indicate a parallel relationship between dividend announcements and share prices; when one rises, the other rises with it, and both fall simultaneously. The results also supported and confirmed the findings of the earlier study by Asiri and Taleb (2012). These results point to a similarity between the markets in Bahrain and Oman as both markets evidence positive effects on stock return in direct response to announcements, while the findings on the Saudi market reflect a clear negative reaction to dividend announcements. This can be attributed to the unique characteristics of each national market that arise from differing cultural practices and differing regulations, which naturally result in varied investor behavior in the face of dividend announcements.

\section{References}

Abeyratna, G., Power, D., \& Lonie, A. (1996). The stock market reaction to dividend announcements. Journal of Economic Studies, 23, 32-52. http://dx.doi.org/10.1108/01443589610106534

Aharony, J., \& Swary, I. (1980). Quarterly Dividend and Earnings Announcements and Stockholders' Returns: An Empirical Analysis. Journal of Finance, 35, 1-12. http://dx.doi.org/10.1111/j.1540-6261.1980.tb03466.x

Allen, F., \& Michaely, R. (2003). Payout policy. In G. Constantinides, M. Harris \& R. Stulz (Eds.), Handbook of Economics. North-Holland, Amsterdam: Elsevier.

Al-Loughani, N. (1995). Random walk in thinly traded stock markets: the case of Kuwait. Arab Journal of Administrative Science, 3, 189-209.

Al-Yahyaee, K., Pham, T., \& Walter, T. (2011). The information content of cash dividend announcements in a unique environment. Journal of Banking \& Finance, 35(3), 606-612. http://dx.doi.org/10.1016/j.jbankfin.2010.03.004

Ambarish, R., John, K., \& Williams, J. (1987). Efficient Signaling with Dividends and Investments. Journal of Finance, 42, 321-344. http://dx.doi.org/10.1111/j.1540-6261.1987.tb02570.x

Asiri, B. (2008). Testing weak-form efficiency in the Bahrain stock market. International Journal of Emerging Markets, 3(1), 38-53. http://dx.doi.org/10.1108/17468800810849213

Asiri, B., \& Al-Zeera, H. (2013). Is the Saudi stock market efficient? A case of weak-form efficiency. Research Journal of Finance and Accounting, 4(6), 35-48.

Asiri, B., \& Talib, E. (2012). The reaction of stock returns to dividend announcement in emerging markets - a case of Bahrain. International Journal of Business and Management Studies, 1.

Asquith, P., \& Mullins, D. Jr. (1983). The Impact of Initiating Dividend Payments on Shareholders' Wealth. Journal of Business, 56, 77-96. http://dx.doi.org/10.1086/296187

Bar-Yosef, S., \& Huffman, L. (1986). The Information Content of Dividends: A Signaling Approach. Journal of Financial and Quantitative Analysis, 21(1). http://dx.doi.org/10.2307/2330990

Black, F. (1976). The Dividend Puzzle. Journal of Portfolio Management, 2, 5-8. http://dx.doi.org/10.3905/jpm.1976.408558 
Bolbol, A., \& Omran, M. (2005). Investment and the stock market: Evidence from Arab firm-level panel data. Emerging Markets Review, 6, 85-106. http://dx.doi.org/10.1016/j.ememar.2004.09.005

Borokhovich, K., Brunarski, K., Harman, Y., \& Kehr, J. (2005). Dividends, corporate monitors, and agency costs. The Financial Review, 40, 57-65. http://dx.doi.org/10.1111/j.0732-8516.2005.00092.x

Brown, S., \& Warner, J. (1985). Using daily stock returns: The case of event studies. Journal of Financial Economics, 14, 3-31. http://dx.doi.org/10.1016/0304-405X(85)90042-X

Chen, D., Liu, H., \& Huang, C. (2009). The Announcement Effect of Cash Dividend Changes on Share Prices. The Chinese Economy, 42(1). http://dx.doi.org/10.2753/CES1097-1475420103

Crutchley, C., \& Hansen, R. (1989). A Test of the Agency Theory of Managerial Ownership, Corporate Leverage, and Corporate Dividends. Financial Management, 18, 36-46. http://dx.doi.org/10.2307/3665795

Easterbrook, F. H. (1984). Two Agency-Cost Explanations of Dividends. American Economic Review, 74(4), $650-659$.

Easton, S. A., \& Sinclair, N. A. (1989). The Impact of Unexpected Earnings and Dividends on Abnormal Returns to Equity. Journal of Accounting \& $\quad$ Finance, $29, \quad 1-19$. http://dx.doi.org/10.1111/j.1467-629X.1989.tb00152.x

Fama, E., \& Babiak, H. (1968). Dividend Policy: An Empirical Analysis. Journal of the American Statistical Association, 63(324), 1132-1161. http://dx.doi.org/10.1080/01621459.1968.10480917

Fama, E., Fisher, L., Jensen, M., \& Roll, R. (1969). The adjustment of stock prices of new information. International Economic Review, 10, 1-20. http://dx.doi.org/10.2307/2525569

Farrelly, E., Baker, H., \& Edelman, R. (1986). Corporate Dividends: Views of Policy Makers. Akron Business and Economic Review, 17(4), 62-74.

Ghosh, C., \& Woolridge, R. (1991). Dividend omissions and stock market rationality. Journal of Business Finance and Accounting, 18, 315-30. http://dx.doi.org/10.1111/j.1468-5957.1991.tb00597.x

Gordon, M. (1959). Dividends, Earnings and Stock Prices. Review of Economics and Statistics, 41, 99-105. http://dx.doi.org/10.2307/1927792

Gordon, M. (1962). The Savings Investment and Valuation of a Corporation. The Review of Economics and Statistics, 44, 37-51. http://dx.doi.org/10.2307/1926621

Gordon, M., \& Bradford, D. (1980). Taxation and the Stock Market Valuation of Capital Gains and Dividends: Theory and Empirical Results. Journal of Public Economics, 109-136. http://dx.doi.org/10.1016/0047-2727(80)90037-7

Graham, R. E., \& Dodd, P. (1951). Security Analysis. McGraw-Hill Book Co.

Grullon, G., Michaely, R., \& Swaminathan, B. (2002). Are dividend changes a sign of firm maturity? Journal of Business, 75, 387-424. http://dx.doi.org/10.1086/339889

Hamid, U. M. (2003). Effect of Dividend Announcement on Shareholders' Value: Evidence from Dhaka Stock Exchange. 573-608.

Hamid, U. M., \& Osman, D. (2008). Effect of Dividend announcement on Shareholders' Value: Evidence from Saudi Arabian Stock Exchange. The International Journal of Business and Finance Research, 2(1).

Jensen, M. (1986). Agency cost of free cash flow, corporate finance and takeovers. American Economic Review Papers and Proceedings, 76, 323-329.

Jensen, M., \& Meckling, W. (1976). Theory of Firm: Managerial Behavior, Agency Cost, and Ownership Structure. Journal of Financial Economics, 3, 306-360. http://dx.doi.org/10.1016/0304-405X(76)90026-X

Johnson, R. R., \& Jensen, G. R. (1997). Federal reserve monetary policy and industry stock returns. Journal of Business Finance and Accounting, 24, 629-644. http://dx.doi.org/10.1111/1468-5957.00125

Kothari, S., \& Warner, W. (1997). Measuring long-horizon security price performance. Journal of Financial Economics, 43, 301-339. http://dx.doi.org/10.1016/S0304-405X(96)00899-9

Lee, B. S. (1995). The Response of Stock Prices to Permanent and Temporary Shocks to Dividends. Journal of Financial and Quantitative Analysis, 30, 1-22. http://dx.doi.org/10.2307/2331250

Lie, E. (2000). Excess funds and agency problems: An empirical study of incremental cash disbursements. Review of Financial Studies, 13, 219-248. http://dx.doi.org/10.1093/rfs/13.1.219 
Lintner, J. (1956). Distribution of incomes of corporations among dividends, retained earnings and taxes. American Economic Review, 46, 97-113.

Mandal, N., \& Rao, N. (2010). Semi-strong form of Indian stock market efficiency: An empirical study. Journal of Management, 1-16.

McCluskey, T., Burton, M., Power, M., \& Sinclair, D. (2006). Evidence on the Irish stock market's reaction to dividend announcements. Applied Financial Economics, 16, 617-628. http://dx.doi.org/10.1080/09603100600639058

Michaely, R., Thaler, R., \& Womack, K. (1995). Price Reactions to Dividend Initiations and Omissions: Overreaction or Drift? Journal of Finance, 50, 573-608. http://dx.doi.org/10.1111/j.1540-6261.1995.tb04796.x

Miller, M., \& Modigliani, F. (1961). Dividend Policy, Growth and the Valuation of Shares. Journal of Business, 34, 411-433. http://dx.doi.org/10.1086/294442

Miller, M., \& Rock, K. (1985). Dividend policy under asymmetric information. Journal of Finance, 40, 10311051. http://dx.doi.org/10.1111/j.1540-6261.1985.tb02362.x

Ogden, J. P. (1994). A Dividend Payment Effect in Stock Returns. Financial Review, 29, $345-369$. http://dx.doi.org/10.1111/j.1540-6288.1994.tb00401.x

Pettit, R. (1972). Dividend announcements, security performance, and capital market efficiency. Journal of Finance, 27, 993-1007. http://dx.doi.org/10.1111/j.1540-6261.1972.tb03018.x

Pruitt, S. W., \& Gitman, L. J. (1991). The interactions between the investments, financing and dividend decisions of major U.S. firms. The Financial Review, 26, 409-430. http://dx.doi.org/10.1111/j.1540-6288.1991.tb00388.x

Rao, D., \& Shankarajah, K. (2003). Stock market efficiency and strategies for developing GCC financial markets: a case study of the Bahrain stock market. The Arab Bank Review, 5(2), 16-21.

Robinson, J. (2006). Dividend Policy among Publicly Listed Firms in Barbados. Journal of Eastern Caribbean Studies, 31(1), 1-36.

Rozeff, S. (1982). Growth, Beta and Agency Costs as Determinants of Dividend- Payout Ratios. Journal of Financial Research, 5(3), 249-259. http://dx.doi.org/10.1111/j.1475-6803.1982.tb00299.x

Ryan, P. A., Besley, S., \& Lee, H. W. (2000). An Empirical Analysis of Reactions to Dividend Policy Changes for Nasdaq Firms. Journal of Financial and Strategic Decisions, 13(1), 35-44.

Soter, D. S., Brigham, E., \& Evanson, P. (1996). The dividend cut heard round the world: The case of FPL. Journal of Applied Corporate Finance, 9, 4-15. http://dx.doi.org/10.1111/j.1745-6622.1996.tb00096.x

Suwanna, T. (2012). Impact of Dividend Announcement on Stock Return. Procedia-Social and Behavioral Sciences, 40, 721-725. http://dx.doi.org/10.1016/j.sbspro.2012.03.255

Videen, G. (2011). Effects of Green Business on Firm Value. The Michigan Journal of Business, 4(1), 107-133.

Walter, J. (1956). Dividend Policies and Common Stock Prices. Journal of Finance, 16, $29-41$. http://dx.doi.org/10.1111/j.1540-6261.1956.tb00684.x

Woolridge, R., \& Ghosh, C. (1985). Dividend cuts: Do they always signal bad news? Midland Corporate Finance Journal, 3, 20-32. 


\section{Appendix A}

List of the companies in the Bahrain Bourse by October 2014

\begin{tabular}{|c|c|c|c|}
\hline Serial & Company Name & Serial & \\
\hline & Commercial Banks & & Services \\
\hline 1 & Al Salam Bank & 28 & Bahrain Car Park \\
\hline 2 & Al Ahli United Bank & 29 & Bahrain Cinema Company \\
\hline 3 & Bahrain Islamic Bank & 30 & Bahrain Duty Free Complex \\
\hline 4 & Bank of Bahrain and Kuwait & 31 & Bahrain Shipping Repairing and Engineering \\
\hline 5 & Ithmar Bank & 32 & Bahrain Telecommunication Company \\
\hline 6 & Khaleeji Commercial Bank & 33 & BMMI \\
\hline \multirow[t]{2}{*}{7} & National Bank of Bahrain & 34 & Nass Corporation \\
\hline & Investment & 35 & Seef Properties \\
\hline 8 & Al Barak Banking Group & 36 & Trafco Group \\
\hline 9 & Arab Banking Corporation & & Hotels and Tourism \\
\hline 10 & Bahrain Commercial Facilities Company & 37 & Bahrain Family Leisure \\
\hline 11 & Bahrain Middle East Bank & 38 & Bahrain Tourism Company \\
\hline 12 & Esterad Investment Company & 39 & Banader Hotels Company \\
\hline 13 & Gulf Finance House & 40 & Gulf Hotel Group \\
\hline 14 & Gulf Monetary Agency (Suspended) & 41 & National Hotels Company \\
\hline 15 & Inovest & & Industrial \\
\hline 16 & Investcorp Bank & 42 & Aluminium Bahrain \\
\hline 17 & Taib Bank (Suspended) & 43 & Bahrain Flour Mills Company \\
\hline 18 & United Gulf Bank & 44 & Delmon Poultry Company \\
\hline \multirow[t]{2}{*}{19} & United Gulf Investment Corporation & & Non-Bahraini Companies \\
\hline & Preferred Shares & 45 & Bank Muscat \\
\hline \multirow[t]{2}{*}{20} & AUB Class A Preference Share (Suspended) & 46 & International Investment Group (Suspended) \\
\hline & Closed Companies & 47 & United Finance Company \\
\hline 21 & Securities and Investment Company & & \\
\hline \multirow[t]{2}{*}{22} & United Paper Industries & & \\
\hline & Insurance & & \\
\hline 23 & Al Ahlia Insurance Company & & \\
\hline 24 & Arab Insurance Group & & \\
\hline 25 & Bahrain and Kuwait Insurance Company & & \\
\hline 26 & Bahrain National Holding Company & & \\
\hline 27 & Takaful International Company & & \\
\hline
\end{tabular}

\section{Copyrights}

Copyright for this article is retained by the author(s), with first publication rights granted to the journal.

This is an open-access article distributed under the terms and conditions of the Creative Commons Attribution license (http://creativecommons.org/licenses/by/3.0/). 